Тамб. гос. ун-т. им. Г. Р. Державина. Тамбов: Изд-во ТГУ им. Г. Р. Державина, 2005. С. 455-457.

10. Півньова Л. В. Мова спеціального призначення як об'єкт лінгвістичних студій / Українська мова. 2014. № 4 (52). С. 117-126.

11. Стасюк Т. В. Терміносфера новітніх технологій: лінгвосоціокогнітивні чинники формування та розвитку: дис. ... д-ра філол. н.: 10.02.01. Київ, 2020. 518 с.

12. Фельде О. В. Языки для специальных целей в историколингвистическом аспекте / Вестник Бурятского государственного университета. Улан-Удэ, 2013. № 10. С. 50-55.

DOI https://doi.org/10.30525/978-9934-26-073-5-2-15

\title{
COMMUNICATIVE AND PRAGMATIC FEATURES OF DRAMATIC TEXTS
}

\author{
Moskalchuk H. O. \\ PhD student of the Institute of Philology \\ Borys Grinchenko Kyiv University \\ Kyiv, Ukraine
}

At the initial stage of its development, pragmatics and its constituent the speech act theory developed by J. Austin and R. Searle - dealt with studying the principles of live communication. In due course, the opinion was formed that the pragmatic aspect is extremely important in the study of a literary text [5].

This article aims to analyze lingual pragmatic features of dramatic text manifested through wordplay.

Indirectness of the pragmatic aspect of the literary text is stipulated by the following: firstly, the author expresses their attitude to reality not directly, but through the prism of the characters; secondly, the author/reader is considered to be generalized predicted communicant (the addressee is not an individual, but a wide range of readers); thirdly, the success of the communication depends on many extratextual factors, such as reader's thesaurus, etc. These features require the author to carefully select linguistic expressive means that will enable the reader to adequately decode the text. In such a case, readers are inherently assumed to be conservatives, while writers should be the embodiments of innovative potential. The perception of the literary text is subject to a framework, which main task is to ensure the maximum possible 
fuse of the reader's horizon of expectations [7] with the author's idea, as only this provides for the adequate comprehension and interpretation of the text. The essence of the writer's lingual creativity is to take into account the reader's expectations and to simultaneously violate them thereby offering a new vision of an already familiar story.

Therefore, the pragmatic aspect of fiction is closely connected to the communicative one and presupposes the following: 1) presence of the communicative chain that includes the author of the literary text, the literary text itself and its reader; 2) the semiotic nature of the literary text requiring the author to preliminary encode the signs of the text and the reader to subsequently decode them; 3 ) a system of dependence of the sign usage on the literary tradition as a system of established literary conventions. The last two conditions open the door for the process of communication itself allowing the reader to interpret the literary text based on their language skills, personal experience etc.

Many scholars acknowledge the infinite possibilities and perspectives inherent in the language. They particularly point out the capability of a word to acquire additional shades of meaning within the text. This can be explained by the fact that a single word can arise various associations in the mind of a language speaker; in fiction, such an abundance of associations has particular expressivity and suggestiveness [1]. Thus, R. Oman introduces the concept of the «imitative speech acts» claiming that imitation of the reality, construction of the fictitious world in the literary text is possible on the condition that writer and reader reach an «agreement» - the so-called «exchange» of illocutionary acts. The brightest embodiment of «imitative speech acts» is a dramatic text.

The dramatic texts are based on dialogical speech, which, according to V. Vinogradov, constitutes a part of various types of prose. It shapes an independent literary genre - a dramatic work, where the verbal language interacts with other systems of expression, namely the body language and mimics [2]. The dramatic text relies on the dialogue that enables the communication between characters (the so-called internal communication). However, the communication in the dramatic text is not limited to character speech only [3]. The dramatic text also contains external communication, which enables the communication at the beginning (author) and the end (reader / viewer) of the communicative text, thereby involving the text in the communicative act, space, process [6]. Therefore, there are two aspects of the dramatic dialogue to study. The internal communication is primary to the external one (author - reader/viewer). The link between internal and external communication is created by stage directions, which were characterized by J. Austin as an elegant tool for clarifying the power of expression or its 
intended meaning [5]. Within the framework of external communication, the author's activity is finite, resulting in the text of the play. In contrast, the reader's activity is infinite. The reader, who is also directly involved in the internal communication, stands as its witness and cannot interfere with the «reality» suggested by the author.

Theatricality is an important feature of communication of the dramatic text. In artistic communication, the factual context appears to the addressee as a continuous theatrical action, which cannot always be recorded by words verbally. The addresser represents themselves in the artistic communication of the play, through character speech and behavior, stage decor, gestures, mimics, voice, intonations, etc. Respectively, the addressee of the play's artistic communication always has an opportunity to complete, continue the trajectory of the character's behavior, the addresser's intentions, thus expanding the boundaries of communication.

The dramatic text also implements all available functions of communication: 1) emotive function (focused on the addresser reflecting their attitude to the topic and situation of communication); 2) connotative (appellative) function (focused on the addressee, expressing triggering, attracting attention, address); 3) referential (denotative) function (context-oriented, focused on the object, topic, subject matter of the discussion, verbalized mainly through the stage directions); 4) poetic function (focused on the message itself determining the significance of the form, rather than content); 5) phatic function (focused on the contact, the use of the communicative system for establishing, keeping and terminating the communication); 6) metalingual function (focused on the lingual code involving the description of parameters of communication and its interpretation).

The heterogeneity of the dramatic text and the diversity of communication participants allows us to single out the stages of the artistic communication of the play [4, 6]: 1) communication in the play as a closed system. It is implemented in the written version of the dramatic text, between the play's characters; 2) stage communication as a process of cooperation between the author and viewers / readers. This stage involves both written and staged variants of the dramatic piece; 3) interpersonal communication that involves the text of the play - as the reason for communication or its intermediary. It involves pretext, written and staged versions of the play; 4) further communication between the author and viewers/readers is mediated through or complicated by the text that contains the response to the original text - the situation when the text begins to live its own life, without the author. 


\title{
References:
}

1. Арноль И.В. (2002) Стилистика. Современный английский язык: Учебник для вузов. 384.

2. Гуцуляк I.Г. (2005) Мовостиль українського поетичного бароко. Вилучено 3: http://irbis-nbuv.gov.ua/ASUA/0078994

3. Корольова В.В. (2017) Сучасний український драматургійний дискурс: комунікативна структура та прагматика. 423.

4. Лотман Ю. (1996) Текст у тексті. 428-441.

5. Сахарова О.В. (2015) Реконструкція мовної особистості в драматургічному дискурсі. Система і структура східнослов'янських мов, (8), 197-207. Вилучено 3: http://nbuv.gov.ua/UJRN/sissm_2015_8_29

6. Синявська Л.I. (2019) Українська драматургія кінця XIX - початку XX століття: комунікативні стратегії. 302.

7. Яусс X.P. (1995) История литературы как провокация литературоведения. С. 34-84.

DOI https://doi.org/10.30525/978-9934-26-073-5-2-16

\section{ПРИНЦИПИ УКЛАДАННЯ КОМУНІКАТИВНОГО ДОВІДНИКА ДЛЯ СОЦІАЛЬНОЇ ВЗАЕМОДІЇ}

\author{
Пелепейченко Л. М. \\ доктор філологічних наук, професор, \\ професор кафедри філології, перекладу та стратегічних комунікачій \\ Начіональної академії Національної гвардії Украӥни \\ м. Харків, Україна
}

Необхідність укладання комунікативного довідника для широкого використання продиктована самим життям і проблемами соціальної комунікативної взаємодії, свідком яких нам доводиться бути протягом останніх років. Доволі часто користувачі Інтернету вимушені відчувати когнітивний дисонанс, спостерігаючи за тим, які приголомшливі заяви роблять представники владних структур у спілкуванні з громадянами, які помилки міжкультурної комунікації вони допускають під час офіційних візитів до інших країн. Здавалось би, високий соціальний статус представників влади, їхня освіченість, інтелектуальність, найкращі моральні якості мали б забезпечити успішність комунікації в будь-якій ситуації проте реальні факти часто не відповідають очікуванням громадськості. Однією з причин названих суперечностей є відсутність лексикографіч- 